\title{
Effect of Saturated Zone on Nitrogen Removal Processes in Stormwater Bioretention Systems
}

\author{
Chuansheng Wang ${ }^{1}$ (D), Fan Wang ${ }^{1}$, Huapeng Qin ${ }^{1, *}$, Xiangfei Zeng $^{1}{ }^{(D)}, X_{\text {ueran } \operatorname{Li}^{1}}$ and \\ Shaw-Lei Yu ${ }^{2}$ \\ 1 Key Laboratory for Urban Habitat Environmental Science and Technology, School of Environment and \\ Energy, Peking University Shenzhen Graduate School, Shenzhen 518055, China; \\ wangcs@sz.pku.edu.cn (C.W.); wangfan@pkusz.edu.cn (F.W.); zengxiangfaye@pku.edu.cn (X.Z.); \\ snowbubu@163.com (X.L.) \\ 2 Department of Civil and Environmental Engineering, School of Engineering and Applied Science, \\ University of Virginia, Charlottesville, VA 22904, USA; sly@virginia.edu \\ * Correspondence: qinhp@pkusz.edu.cn
}

Received: 9 December 2017; Accepted: 2 February 2018; Published: 7 February 2018

\begin{abstract}
The introduction of a saturated zone (SZ) has been recommended to address the issue of nitrogen removal fluctuation in the bioretention system, which is one of the most versatile low-impact development facilities for urban stormwater management. Nine experimental columns were used to characterize the nitrogen concentration variations over the outflow during wetting periods and in SZ during the antecedent drying periods (ADPs), as well as compare removal efficiencies of various nitrogen species in systems with different $\mathrm{SZ}$ depths under alternate drying and wetting conditions. Results indicated that $\mathrm{NO}_{3}{ }^{-}-\mathrm{N}$ concentrations in the outflow showed quasi-logistic curve-shaped variations over time: being low $(<0.5 \mathrm{mg} / \mathrm{L})$ in the early process, sharply increasing thereafter, and finally flattening around $3.0 \mathrm{mg} / \mathrm{L}$ with $\mathrm{NO}_{3}{ }^{-}$leaching; $\mathrm{NH}_{4}{ }^{+}-\mathrm{N}$ and organic nitrogen $(\mathrm{ON})$ concentrations were consistently low around $0.5 \mathrm{mg} / \mathrm{L}$ and $1.8 \mathrm{mg} / \mathrm{L}$, respectively during the wetting periods. $\mathrm{NH}_{4}{ }^{+}$removal efficiency in bioretention systems was consistently high around $80 \%$, not varying with the increasing SZ depth; ON removal efficiency had a slight rise from $57 \%$ to $84 \%$ and $\mathrm{NO}_{3}{ }^{-}$removal efficiency was significantly enhanced from $-23 \%$ to $62 \%$ with the $\mathrm{SZ}$ depth increasing from 0 to $600 \mathrm{~mm}$. Deeper SZ could store more runoff and promote more denitrification of $\mathrm{NO}_{3}{ }^{-}$and mineralization of $\mathrm{ON}$ during the ADPs, providing more "old" water with low $\mathrm{NO}_{3}{ }^{-}$and $\mathrm{ON}$ concentrations for water exchange with "new" inflow of higher $\mathrm{NO}_{3}{ }^{-}$and $\mathrm{ON}$ concentrations during the wetting periods. The total nitrogen (TN) removal, a combined result of the instantaneous removal through adsorption and retention in the upper soil layer during the wetting periods and the gradual removal via denitrification and mineralization in SZ during the ADPs, was also improved by increasing the SZ depth; TN removal efficiency was elevated from $35 \%$ to $73 \%$ when the SZ depth increased from zero to $600 \mathrm{~mm}$.
\end{abstract}

Keywords: bioretention; saturated zone; nitrogen removal; leaching; drying and wetting

\section{Introduction}

With the rapid development of urbanization, nitrogen pollution in storm runoff has aroused widespread public concerns [1]. It is well known that excessive nitrogen, some from urban or agricultural runoff, is one of the main contaminants contributing to eutrophication in many water bodies [1-4]. Managing stormwater runoff has therefore become an important task in water quality protection. In recent years, low-impact development (LID) has been proposed as an ecologically and economically sustainable approach to stormwater management around the world [5]. Bioretention (also referred to as rain garden or biofiltration), consisting essentially of vegetation, mulch, soil media, 
sand layer and gravel sump, is a widespread LID technology that has proved to be effective in removing phosphorus, suspended solids, chemical oxygen demand and heavy metals [6-12]. However, previous research indicated that the removal efficiencies of nitrogenous pollutants varied dramatically in bioretention systems [13-16]. While ammonium $\left(\mathrm{NH}_{4}{ }^{+}\right)$and organic nitrogen $(\mathrm{ON})$ removal were normally effective due to the retention and adsorption processes in media layer of bioretention systems, total nitrogen (TN) removal fluctuated because of nitrate $\left(\mathrm{NO}_{3}{ }^{-}\right)$leaching in bioretention systems $[6,14,17,18]$.

In recent times, the introduction of a saturated zone (SZ) into bioretention systems has been widely recommended to promote nitrogen removal and address the issue of nitrate removal fluctuation [10,19-23]. This is because SZs can create an anaerobic environment to promote permanent $\mathrm{NO}_{3}{ }^{-}$removal via denitrification. Despite the growing interests in bioretention systems with SZs, reported nitrogen removal efficiencies were still not consistent in different studies. For example, some researchers found $\mathrm{SZ}$ combined with carbon source could remove $\mathrm{NO}_{3}{ }^{-}$from roof runoff by up to $67 \%$ [24], others reported that $\mathrm{SZ}$ could effectively remove more than $90 \%$ of $\mathrm{NO}_{3}{ }^{-}$from stormwater runoff $[25,26]$. However, a few studies revealed that nitrogen removal was even less than $20 \%$ and $\mathrm{NO}_{3}{ }^{-}$leaching even occurred occasionally in bioretention systems with SZ design $[13,18,27]$. Therefore, in view of the controversy over the effectiveness of SZs, there is a need to understand the nitrogen removal processes that in essence account for the variabilities of various nitrogen removal efficiencies in different bioretention systems with SZs.

Given that depth is one of the most critical parameters for SZ design, various nitrogen removal efficiencies of bioretention systems with SZ depths of 0, 150, 450, $600 \mathrm{~mm}$ were compared by Zinger et al [19]. Their results showed that $\mathrm{NO}_{3}{ }^{-}$and $\mathrm{TN}$ removal efficiencies increased with the increase of the $\mathrm{SZ}$ depth and were up to $99 \%$ in systems with 450 and $600 \mathrm{~mm}$ deep SZs. However, they mainly focused on the nitrogen removal efficiencies during storm events (wetting periods) and did not investigate the removal processes under alternate drying and wetting conditions that could help probe into the influence mechanism of SZ on nitrogen removal.

This study is a further in-depth investigation of the effect of saturated zone on the nitrogen removal with the objectives to depict the major nitrogen removal processes in bioretention systems and provide implications into SZ design for bioretention systems under alternate drying and wetting conditions. In detail, we have characterized the nitrogen concentration variations over the outflow course during the wetting periods and in SZ during the antecedent drying periods (ADPs); the removal performance of $\mathrm{NH}_{4}{ }^{+}, \mathrm{ON}, \mathrm{NO}_{3}{ }^{-}$and $\mathrm{TN}$ between systems with different $\mathrm{SZ}$ depths were also compared; finally, different removal pathways for different nitrogen species were proposed in bioretention systems with SZs.

\section{Methods}

\subsection{Experimental Set-up}

Nine bioretention columns were built at the campus of Peking University Shenzhen Graduate School (PKUSZ), China in 2016. Each of them consisted of five layers from top to bottom: experimental vegetation, mulch layer, mixed soil media, sand bed, and gravel sump, which were all placed in the Polymeric Methyl Methacrylate (PMMA, with good rigidity and durability) cylinder containers (Figure 1a and Table 1). The first set of bioretention systems included three mesocosm bioretention columns $500 \mathrm{~mm}$ in diameter (two with $300 \mathrm{~mm} \mathrm{SZ}$ and one without SZ). The second set included six columns $250 \mathrm{~mm}$ in diameter (referred to as "small-scale bioretention systems" thereinafter) with 0-600 mm SZ (Table 1 and Figure 1). Bulrushes (Phragmites australis, forty per mesocosm column, ten in each smaller one) were planted as experimental vegetation in the clear top section of each column, while the next four layers were wrapped up in tinfoil to be isolated from outside heat (Figure 1b). The first $50 \mathrm{~mm}$ deep mulch layer was comprised of wood chips (from local pine trees), and the next $450 \mathrm{~mm}$ deep mixed soil layer was composed of 50\% (by weight) sandy loam soil from the campus 
of PKUSZ, $40 \%$ sand ( $\mathrm{d}_{50}$ of approximately $0.5 \mathrm{~mm}$ in size), $10 \%$ peat moss (Pindstrup Sphagnum). An additional amount of lime (calcium carbonate) was added into this mixed soil layer to achieve a $\mathrm{pH}$ of 6.5-7.5 as recommended by several construction manuals [28-30]. Below it, the 120-mm deep transition layer was composed of river sand ( $\mathrm{d}_{50}$ of $1-2 \mathrm{~mm}$ in size). At the bottom, $300 \mathrm{~mm}$ high gravel sump combined with carbon source (newspaper, $5 \%$ by volume) was installed in the three mesocosm bioretention columns. In six small-scale columns, embedded elbow pipes (diameter $25 \mathrm{~mm}$ ) at the draining ports were raised to the heights of $0,200-600 \mathrm{~mm}$ to create anaerobic saturated conditions in the gravel sumps.

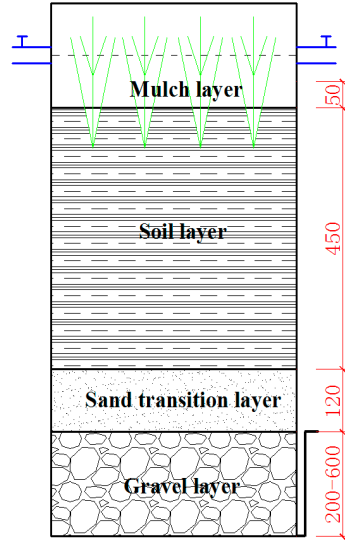

(a)

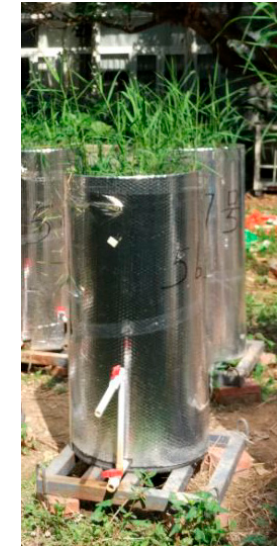

(b)

Figure 1. Bioretention Columns: Structure details (a) and experiment site pictures (b). Unit: mm.

Table 1. The media in the bioretention columns.

\begin{tabular}{ccc}
\hline Media Layer & Depth $(\mathbf{m m})$ & Material \\
\hline Mulch & 50 & Wood chips \\
Soil layer & 450 & Sandy loam \\
Transition layer & 120 & River sand (1-2 mm) \\
Saturated zone & $0,200,300,400,500,600$ & Gravel and Carbon source \\
\hline
\end{tabular}

The experimental bulrushes were carefully cultivated from root to seedlings under controlled laboratory conditions for two months from December 2015 to February 2016. Then all bioretention columns were placed into a transparent canopy, which ensured enough natural sunlight but avoided rainfall entering the columns.

Based on typical subtropical coastal climate conditions in Shenzhen, a twice-weekly dosing scheme with synthetic runoff (intensity: $\sim 20 \mathrm{~mm} / \mathrm{h}$, duration: one hour) was adopted. Each bioretention system was sized at $5 \%$ of the catchment area. This dosing method was similar to that used in previous studies $[18,28,31]$. Synthetic runoff in this study was prepared to mimic local highly polluted runoff characteristics of chemical oxygen demand (COD), organic nitrogen (ON), ammonium-nitrogen $\left(\mathrm{NH}_{4}{ }^{+}-\mathrm{N}\right)$, nitrate-nitrogen $\left(\mathrm{NO}_{3}{ }^{-}-\mathrm{N}\right)$ and $\mathrm{pH}$ 6.5-7.5 (Table 2), according to Huang et al [32]. Each column was watered with experimental synthetic runoff (Table 2) to allow plant growth for four weeks until March 2016 to achieve stability.

Table 2. The mean inflow concentrations of pollutants in the synthetic runoff.

\begin{tabular}{ccc}
\hline Pollutant & Mean Inflow Concentration & Source \\
\hline Chemical Oxygen Demand & $200 \mathrm{mg} / \mathrm{L}$ & Glucose $\left(\mathrm{C}_{6} \mathrm{H}_{12} \mathrm{O}_{6}\right)$ \\
$\mathrm{NO}_{3}{ }^{-}-\mathrm{N}$ & $2.5 \mathrm{mg} / \mathrm{L}$ & Potassium Nitrate $\left(\mathrm{KNO}_{3}\right)$ \\
$\mathrm{NH}_{4}{ }^{+}-\mathrm{N}$ & $2.5 \mathrm{mg} / \mathrm{L}$ & Ammonium Chloride $\left(\mathrm{NH}_{4} \mathrm{Cl}\right)$ \\
$\mathrm{ON}$ & $5.0 \mathrm{mg} / \mathrm{L}$ & 3-Aminopropanoic $\left(\mathrm{C}_{3} \mathrm{H}_{7} \mathrm{NO}_{2}\right)$ \\
\hline
\end{tabular}




\subsection{Experimental Procedure}

\subsubsection{Mesocosm Bioretention Systems}

The three mesocosm bioretention systems were dosed with $70 \mathrm{~L}$ synthetic runoff for one hour at three-day intervals for five storm events (also called five wetting periods) during March to April, 2016 (at $23{ }^{\circ} \mathrm{C} \sim 30{ }^{\circ} \mathrm{C}$ ). The outflow was monitored over the 1-h wetting period with nine sub-samples taken after draining about $0,1 \%, 10 \%, 16.7 \%, 33.3 \%, 50 \%, 66.7 \%, 83.3 \%$ and $100 \%$ of integrated outflow volume. In addition, the entire outflow was thoroughly mixed to form one final composite sample for each column.

After one wetting period, the stored water in SZ was monitored every hour within the first ten-hour drying period and then every $12 \mathrm{~h}$ in the remaining ADPs. Various nitrogen removal efficiencies of $\mathrm{NH}_{4}{ }^{+}, \mathrm{NO}_{3}{ }^{-}, \mathrm{ON}$ and $\mathrm{TN}$ between systems with and without SZs were compared. DO in SZ was also detected by sensor online monitor meter (NUL-205, Neuron Logger Sensors, USA) every two hours during the ADPs.

\subsubsection{Small-Scale Bioretention Systems}

The six small-scale systems with 0-600 $\mathrm{mm}$ deep SZ were dosed with $20 \mathrm{~L}$ per hour at three-day intervals during April to May, 2016 (at $25^{\circ} \mathrm{C} \sim 31^{\circ} \mathrm{C}$ ), and five wetting periods were monitored as well. The outflow was monitored over the 1 -h wetting period with five sub-samples taken after draining about $0,25 \%, 50 \%, 75 \%$ and $100 \%$ of integrated outflow volume. In addition, the entire outflow was mixed thoroughly to form one final composite sample for each column.

\subsection{Sample Analysis}

The inflow volume and flow rate were controlled by the metering pump to maintain consistence during the wetting periods. According to Standard Methods for the Examination of Water and Wastewater (2012), after collection, the samples were immediately filtered through 0.22- $\mu \mathrm{m}$ membrane filter and then kept frozen at $-20{ }^{\circ} \mathrm{C}$ to prevent microbial activities before further analysis. $\mathrm{NH}_{4}{ }^{+}, \mathrm{NO}_{3}{ }^{-}$and $\mathrm{NO}_{2}{ }^{-}$concentrations were measured using the CleverChem 200+ automatic discontinuous analyzer based on the monitoring methods of Nessler's reagent spectrophotometry, the Hydrazine Sulfate-NEDD spectrophotometry, sulfanilamide and N-(1-naphthalene) ethylenediamine hydrochloride spectrophotometry, respectively. TN was completely converted to $\mathrm{NO}_{3}{ }^{-}$by the alkaline potassium persulfate digestion method for measurements, while $\mathrm{ON}$ was determined by the formula: $\mathrm{ON}=\mathrm{TN}-\mathrm{NO}_{3}{ }^{-}-\mathrm{NO}_{2}{ }^{-}-\mathrm{NH}_{4}{ }^{+}$. In addition, the $\mathrm{pH}$ of each sample was monitored by laboratory pH meter (IE438, Mettler, Greifensee, Switzerland).

In this study, the event mean concentration (EMC) removal method, recommended by the American Society of Civil Engineers and the Environmental Protection Agency (ASCE-EPA) [33], was used to calculate the removal efficiency:

$$
\text { Removal efficiency }=\left[\frac{E M C_{i}-E M C_{0}}{E M C_{i}}\right] \times 100 \%
$$

where $E M C_{i}$ and $E M C_{0}$ were the $E M C$ s of various nitrogen species $\left(\mathrm{NH}_{4}{ }^{+}, \mathrm{ON}, \mathrm{NO}_{3}{ }^{-}\right.$and $\left.\mathrm{TN}\right)$ in the inflow and outflow during the wetting period, respectively.

All figures, including scatter plots and the box-and-whisker plots, were made using OriginPro 2015 (OriginLab Corp., Northampton, MA, USA). Statistical significant difference analyses were performed by the statistical software package PASW Statistics 19.0 (SPSS Inc., Chicago, IL, USA). Two-way ANOVA was used to test the significant difference in the removal efficiencies of various nitrogen species between systems with different SZs, the existence of SZ (i.e., with SZ and without SZ) was selected as the fixed factor and the nitrogen removal efficiencies as the dependents. The $p<0.05$ was accepted as the threshold of significance. 


\section{Results}

The retention rate about $12 \%$ was nearly the same between replicate systems: In the three mesocosm bioretention systems, when the inflow of each event was exactly $70 \mathrm{~L}$ in volume, the outflow volume was consistently similar around $61.7 \mathrm{~L}$; In the six small-scale bioretention systems, when the inflow of each event was exactly $20 \mathrm{~L}$ in volume, the outflow volume of each column ranged from 17.5 to $17.7 \mathrm{~L}$. The $\mathrm{pH}$ of each sample was stable at $7.0 \pm 0.5 . \mathrm{NO}_{2}{ }^{-}$concentrations in all samples were below detection limit $\left(<0.1 \mathrm{mg} / \mathrm{L}^{-1}\right)$, and this study would focus on the removal efficiencies and time-based concentrations of $\mathrm{NH}_{4}{ }^{+}, \mathrm{NO}_{3}{ }^{-}, \mathrm{ON}$ and $\mathrm{TN}$.

\subsection{Variations in Nitrogen Concentrations over the Outflow Process}

Variations in the average $\mathrm{NH}_{4}{ }^{+}, \mathrm{NO}_{3}{ }^{-}, \mathrm{ON}$ and $\mathrm{TN}$ concentrations (for five wetting periods) over the outflow course in the mesocosm bioretention columns in the presence and absence of SZ were presented in Figure 2. $\mathrm{NO}_{3}{ }^{-}$concentrations varied over time: being low in the early outflow process, rapidly increasing thereafter, and finally flattening, displaying quasi-logistic curve-shaped variations. $\mathrm{NO}_{3}{ }^{-}$leaching with the ultimate concentrations exceeding the inflow $\mathrm{NO}_{3}{ }^{-}$concentration of $2.5 \mathrm{mg} / \mathrm{L}$ often occurred in the final outflow process during wetting periods. Meanwhile, in the absence of SZ, $\mathrm{NO}_{3}{ }^{-}$leaching began earlier over the outflow course. Instead, during each wetting period, $\mathrm{NH}_{4}{ }^{+}$and ON concentrations were consistently low, around $0.5 \mathrm{mg} / \mathrm{L}$ and $1.8 \mathrm{mg} / \mathrm{L}$, respectively in bioretention systems with or without the SZ. TN concentrations showed the similar characteristic variations of $\mathrm{NO}_{3}{ }^{-}$over the whole outflow process (Figure 2).
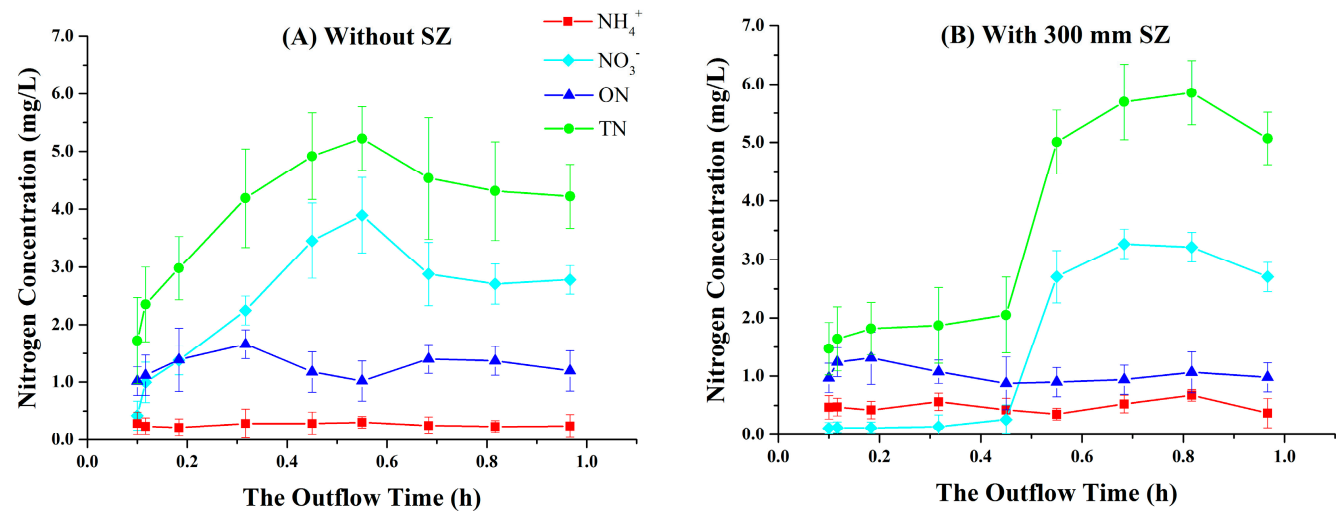

Figure 2. The variations in the average outflow ammonium $\left(\mathrm{NH}_{4}{ }^{+}\right)$, nitrate $\left(\mathrm{NO}_{3}{ }^{-}\right)$, organic nitrogen $(\mathrm{ON})$ and total nitrogen (TN) concentrations for five simulated wetting periods with time. The bars indicate the standard deviations of nitrogen concentration. (A) variations of nitrogen concentrations in bioretention columns with $300 \mathrm{~mm} \mathrm{SZ}$; (B) variations of nitrogen concentrations in bioretention columns without SZ.

\subsection{Variations in Nitrogen Concentrations in SZ during Drying Periods}

During the 3-day antecedent drying periods (ADPs), DO was consistently low, generally less than $0.5 \mathrm{mg} / \mathrm{L}$ in SZ. Variations in the average $\mathrm{NH}_{4}{ }^{+}, \mathrm{NO}_{3}{ }^{-}, \mathrm{ON}$ and $\mathrm{TN}$ concentrations in $\mathrm{SZ}$ during ADPs were displayed in Figure 3. Significant removal was observed in $\mathrm{SZ}$ with $\mathrm{NO}_{3}{ }^{-}$concentrations decreasing from around the inflow concentration of $2.5 \mathrm{mg} / \mathrm{L}$ to almost zero within $12 \mathrm{~h}$, while ON removal also mainly occurred within $12 \mathrm{~h}$ but the final ON concentrations were around $1.0 \mathrm{mg} / \mathrm{L}$. $\mathrm{NH}_{4}{ }^{+}$concentrations were relatively consistent in $\mathrm{SZ}$ without change. TN concentrations revealed similar removal patterns of $\mathrm{NO}_{3}{ }^{-}$during the ADPs (Figure 3). 


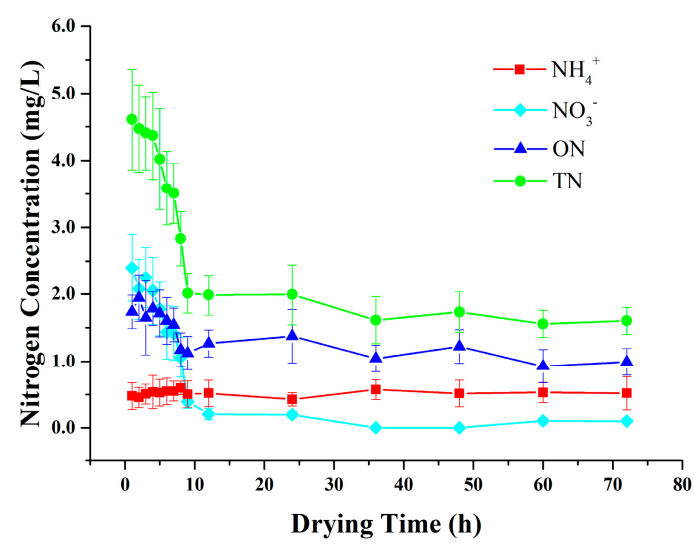

Figure 3. The variations in the average ammonium $\left(\mathrm{NH}_{4}{ }^{+}\right)$, nitrate $\left(\mathrm{NO}_{3}{ }^{-}\right)$, organic nitrogen $(\mathrm{ON})$ and total nitrogen $(\mathrm{TN})$ concentrations in the saturated zone of bioretention systems during antecedent drying periods (ADPs). The bars indicate the standard deviations of nitrogen concentration.

\subsection{Effect of the Presence of SZ on Nitrogen Removal}

Nitrogen removal efficiencies in bioretention systems with and without SZs were presented in Figure 4. The deviations from averages of various nitrogen species removal efficiencies in bioretention with $300 \mathrm{~mm}$ SZ were obviously less than the bioretention without SZ. The ANOVA analysis revealed that there were significant differences in the nitrogen removal efficiencies between the systems with and without the SZ ( $p<0.01$ for $\mathrm{NH}_{4}{ }^{+}, p<0.05$ for $\mathrm{NO}_{3}{ }^{-}, p<0.05$ for $\left.\mathrm{ON}\right)$. In the presence of $\mathrm{SZ}$ in bioretention systems, $\mathrm{NO}_{3}{ }^{-}$removal was significantly promoted, $\mathrm{ON}$ removal was slightly enhanced, while $\mathrm{NH}_{4}{ }^{+}$removal efficiency was somewhat lowered. TN removal efficiency reflected the combination of $\mathrm{NH}_{4}{ }^{+}, \mathrm{NO}_{3}{ }^{-}$and $\mathrm{ON}$.
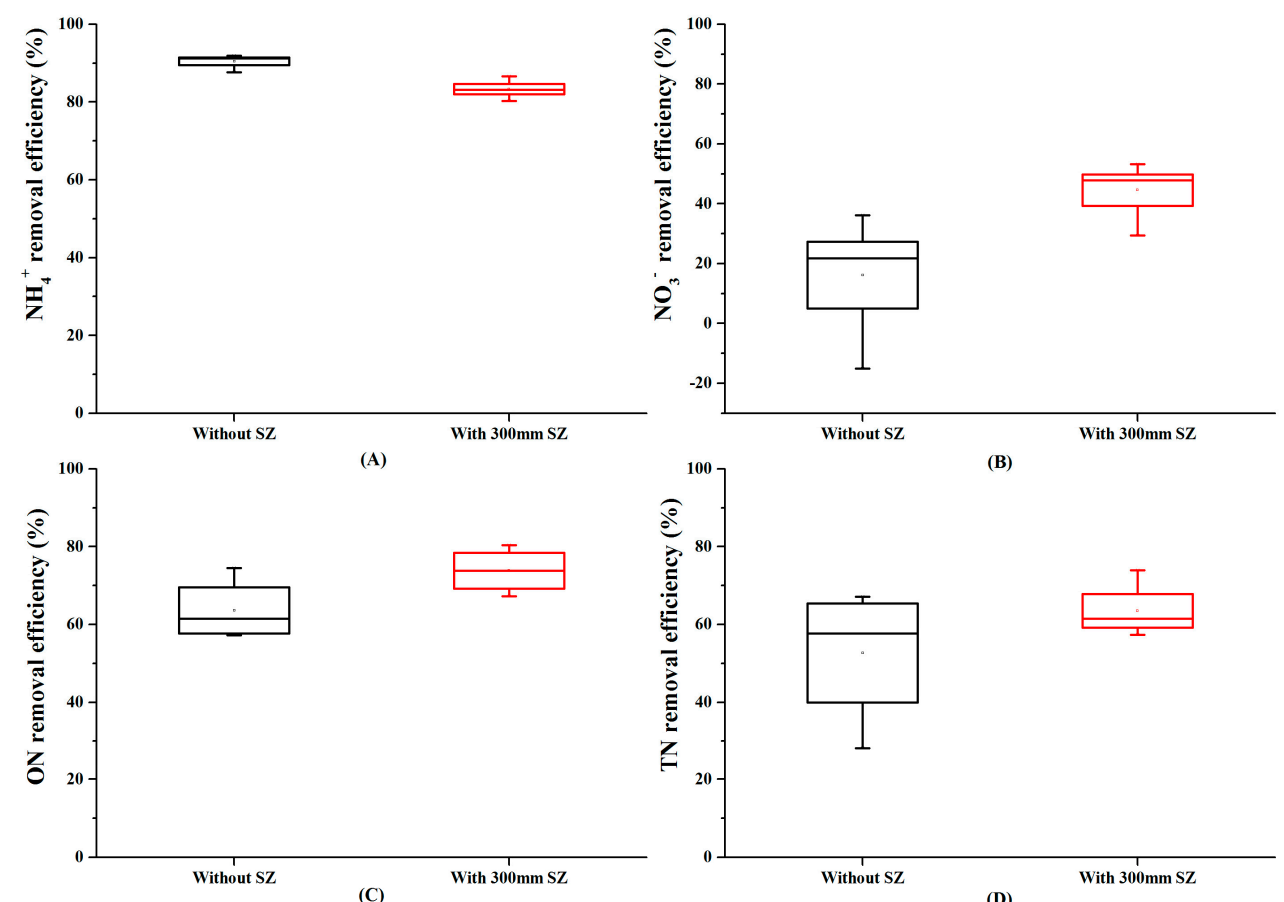

Figure 4. The removal efficiency of ammonium (A), nitrate (B), organic nitrogen (C) and total nitrogen (D) between the system with SZ and non-SZ system. The description of the above box- and whiskerplots: the bottom and top of the box are the first and third quartiles, and the band inside the box is the median. The ends of the whiskers represent the minimum and maximum of all of the data. 


\subsection{Effect of SZ Depths on Nitrogen Removal}

In six small-scale bioretention columns with different $\mathrm{SZ}$ depths, the average $\mathrm{NO}_{3}{ }^{-}$concentrations for five wetting periods showed similar quasi-logistic curve-shaped variations over time (Figures 4 and 5). Likewise, $\mathrm{NO}_{3}{ }^{-}$leaching occurred in the latter outflow process without regard to the $\mathrm{SZ}$ depth. Furthermore, in bioretention systems with deeper SZ, the early outflow process with low $\mathrm{NO}_{3}{ }^{-}$concentrations was extended and $\mathrm{NO}_{3}{ }^{-}$leaching was delayed to occur in the final outflow process with lower peak concentrations (Figure 5B). Instead, with the increase of $\mathrm{SZ}$ depth, $\mathrm{NH}_{4}{ }^{+}$and ON concentrations did not significantly fluctuate over the outflow course and remained consistent between systems with different SZ depths (Figure 5A,C). TN concentrations showed quasi-logistic curve-shaped variations over the whole outflow process. With the increase of SZ depth, the outflow process with low nitrogen concentrations was extended and the peak of nitrogen concentrations was lowered (Figure 5D).
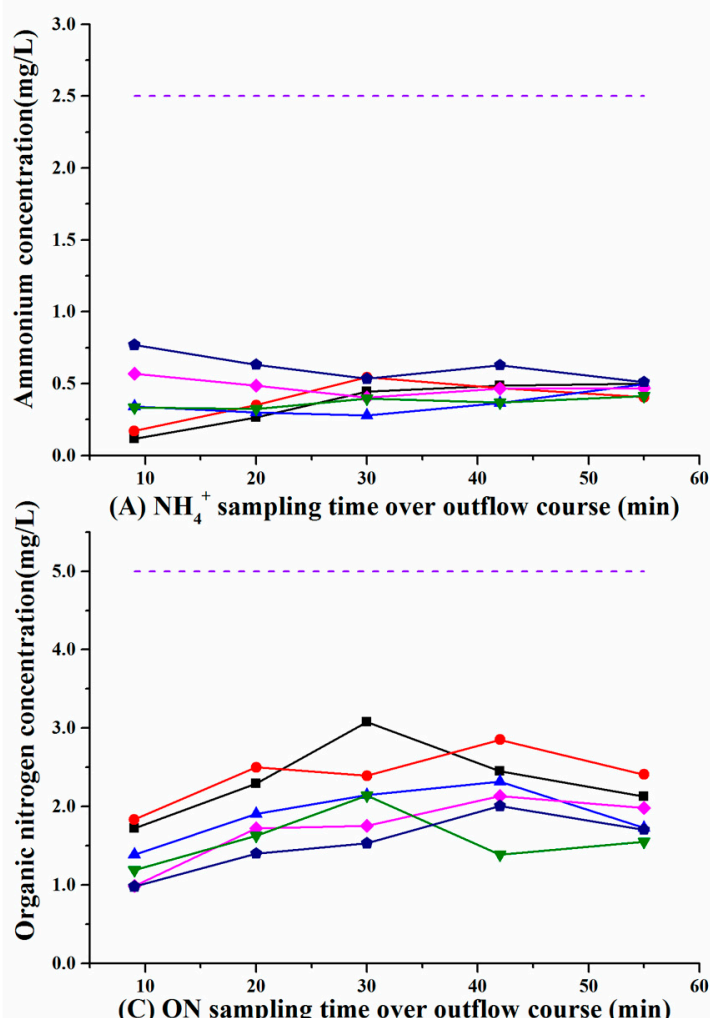

(C) ON sampling time over outflow course (min)

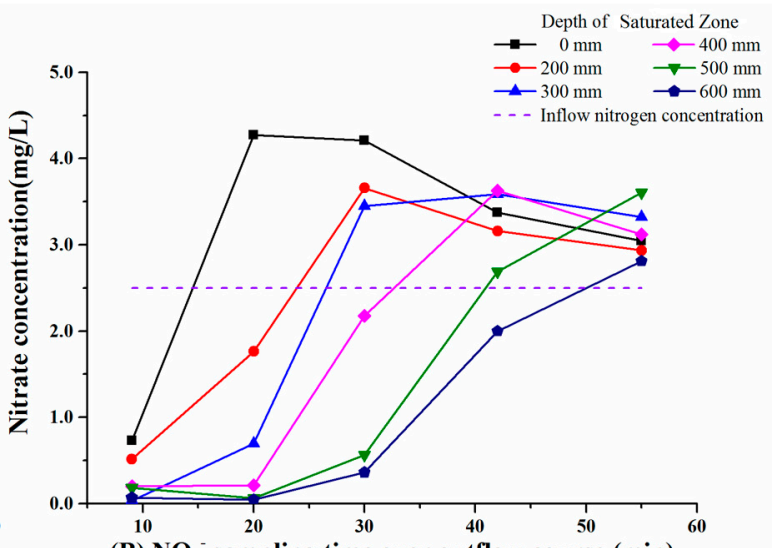

(B) $\mathrm{NO}_{3}^{-}$sampling time over outflow course (min)

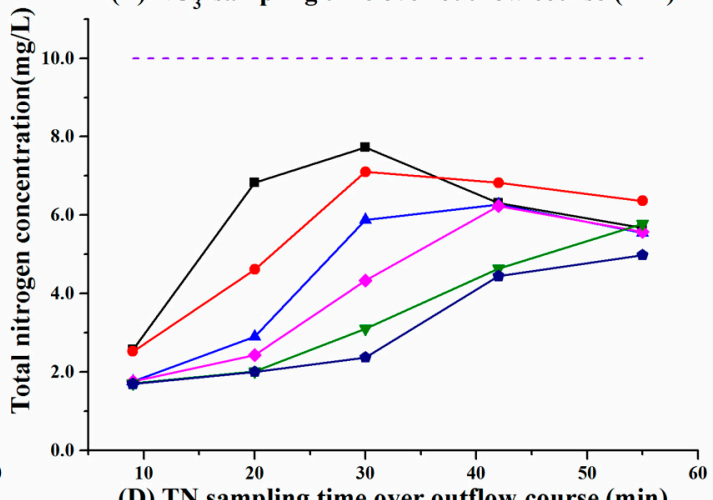

(D) TN sampling time over outflow course (min)

Figure 5. The variations in the average ammonium (A), nitrate (B), organic nitrogen $(\mathbf{C})$ and total nitrogen (D) concentrations in the outflow over time during simulated wetting periods with different saturated zone depths.

Removal efficiencies of $\mathrm{NH}_{4}{ }^{+}$were hardly affected by SZ depth, whereas $\mathrm{NO}_{3}{ }^{-}, \mathrm{ON}$ and TN removal was significantly affected by the SZ depth. Particularly, significant difference of nitrogen removal efficiencies existed between the systems with large-depth difference $(p<0.05)$. All bioretention systems were highly effective in $\mathrm{NH}_{4}{ }^{+}$removal with the EMC removal efficiencies ranging from $79 \%$ $\pm 5 \%$ to $87 \% \pm 5 \%$ and their performance was relatively stable in systems with different SZ depths (Figure 6). However, $\mathrm{NO}_{3}{ }^{-}$removal efficiency increased significantly with the $\mathrm{SZ}$ depth, which varied from $-23 \% \pm 50 \%$ (net leaching and high variations) without SZ to $62 \% \pm 15 \%$ with $600 \mathrm{~mm}$ deep SZ (Figure 6). Also, ON removal efficiency rose from $57 \% \pm 10 \%$ to $84 \% \pm 8 \%$ when the SZ depth increased from zero to $600 \mathrm{~mm}$ (Figure 6). Accordingly, the removal efficiency of TN (the sum of $\mathrm{NH}_{4}{ }^{+}$, 
$\mathrm{NO}_{3}{ }^{-}$and $\mathrm{ON}$ ) increased from $35 \% \pm 18 \%$ without $\mathrm{SZ}$ to $73 \% \pm 5 \%$ with the SZ depth of $600 \mathrm{~mm}$ (Figure 6).

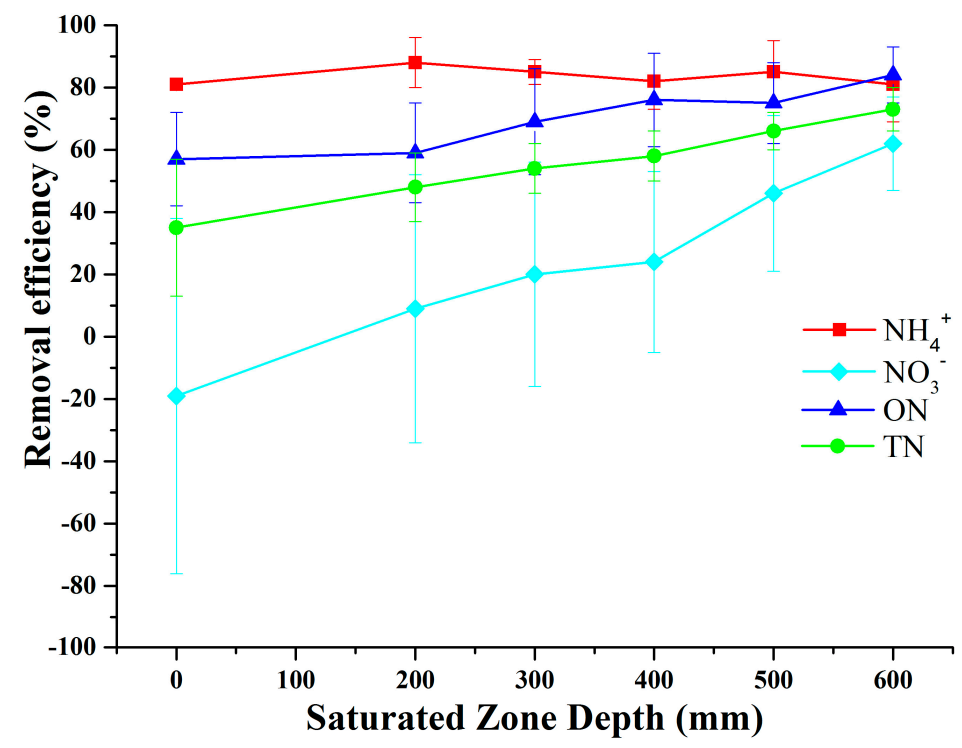

Figure 6. Variations in the average ammonium $\left(\mathrm{NH}_{4}{ }^{+}\right)$, nitrate $\left(\mathrm{NO}_{3}{ }^{-}\right)$, organic nitrogen (ON) and total nitrogen (TN) removal efficiencies for five simulated wetting periods with SZ depths. The bars indicate the standard deviations of nitrogen concentration.

\section{Discussion}

\subsection{Ammonium Removal}

$\mathrm{NH}_{4}{ }^{+}$could be removed by volatilization, media adsorption, plant assimilation and microbial nitrification in bioretention systems [34]. In this study, $\mathrm{NH}_{4}{ }^{+}$volatilization should be generally minimal since the $\mathrm{pH}$ of mixed soil or sand was around 7.0 \pm 0.5 . Adsorption could occur instantaneously after the inflow of synthetic runoff, but mainly in the upper section of bioretention systems with its capacity depending on the physical properties of soil media such as cation exchange capacity [34]. Plant assimilation could also be quickly initiated by the nutrient-laden inflow [35], which mainly occurs in the rhizosphere (approximately the upper 0-30 cm of the soil layer for Phragmites australis). Microbial nitrification was not significant during the wetting periods due to the short duration of one hour $[17,34]$, but may mainly account for the $\mathrm{NH}_{4}{ }^{+}$losses from the soil during antecedent drying periods (ADPs) by converting $\mathrm{NH}_{4}{ }^{+}$to $\mathrm{NO}_{3}{ }^{-}$(Figure 7). Microbial nitrification is typically an aerobic process that should also be limited to occur in the upper aerobic section. Therefore, $\mathrm{NH}_{4}{ }^{+}$removal should mainly occur in the upper section of bioretention systems, and the introduction of an anaerobic $\mathrm{SZ}$ in the bottom had little effect on $\mathrm{NH}_{4}{ }^{+}$removal so that different $\mathrm{SZ}$ depths in each bioretention exerted a negligible influence on $\mathrm{NH}_{4}{ }^{+}$removal. This is in line with similarly high $\mathrm{NH}_{4}{ }^{+}$removal efficiencies in bioretention systems with different SZ depths (Figure 6), as reported by the previous studies [6-9,11]. The significant difference $\left(p<0.01\right.$ for $\left.\mathrm{NH}_{4}^{+}\right)$between the system with $300 \mathrm{~mm} \mathrm{SZ}$ and the non-SZ system revealed that the slight decrease of $\mathrm{NH}_{4}{ }^{+}$removal may be due to the effective mineralization of $\mathrm{ON}$ in SZ, this is in line with the minor decrease of ON during the ADPs (Figure 3). 


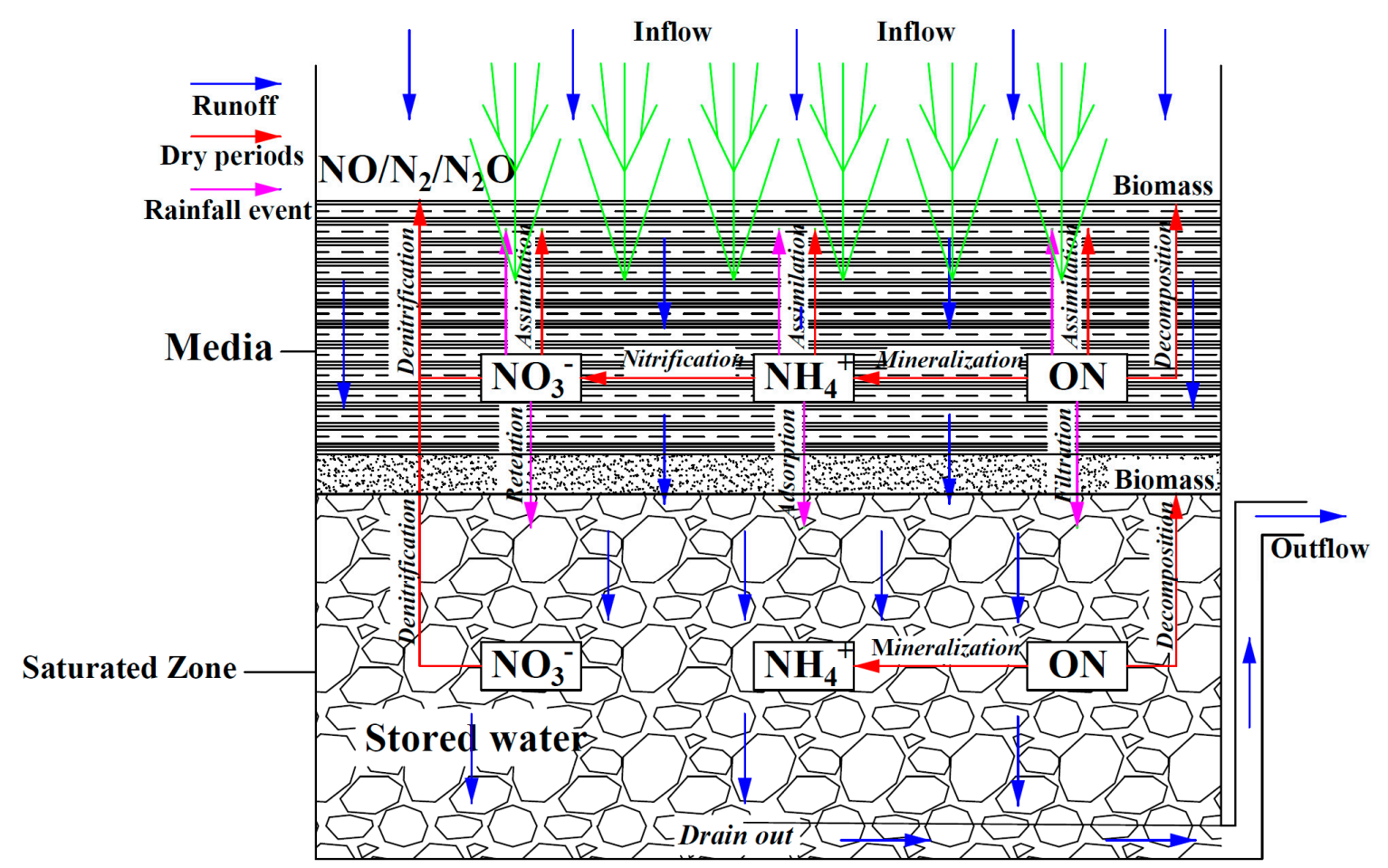

Figure 7. The diagram showing nitrogen processes that mainly occur in SZ and media layer of a bioretention system under alternate drying and wetting periods.

\subsection{Nitrate Removal}

$\mathrm{NO}_{3}{ }^{-}$could possibly be removed by several physical and microbial processes [17,34]. During wetting periods, due to its negative charge, $\mathrm{NO}_{3}{ }^{-}$is unlikely to be retained effectively by soil media in that most of the soil particles are negatively charged [34]. Besides, $\mathrm{NO}_{3}{ }^{-}$is soluble, and hydrological downward washing of $\mathrm{NO}_{3}{ }^{-}$from the soil media could lead to significant leaching of $\mathrm{NO}_{3}{ }^{-}$. Microbial denitrification is a permanent nitrogen removal pathway by transforming $\mathrm{NO}_{3}{ }^{-}$to gaseous nitrogen forms ( $\mathrm{NO}, \mathrm{N}_{2} \mathrm{O}$ and $\mathrm{N}_{2}$ ) via denitrifiers [34] and promoting denitrification becomes a major solution to improving nitrogen removal performance for bioretention systems. Meanwhile, $\mathrm{NO}_{3}{ }^{-}$can be produced by nitrifiers that convert $\mathrm{NH}_{4}{ }^{+}$to $\mathrm{NO}_{3}{ }^{-}$via nitrification. However, denitrification or nitrification is not likely to occur significantly within the short-time (around $1 \mathrm{~h}$ ) wetting period [36], but should mainly occur during the ADPs. The introduction of an SZ with stored runoff could pose little effect on nitrification (mostly aerobic process) but significantly affect denitrification by facilitating the growth of anaerobic denitrifiers to promote the removal of $\mathrm{NO}_{3}{ }^{-}$during the ADPs [20,34,36-38]. This can explain the growing $\mathrm{NO}_{3}{ }^{-}$removal efficiencies with the increasing $\mathrm{SZ}$ depths (Figure 6), which can be strongly supported by the significant difference of ANOVA analysis $\left(p<0.05\right.$ for $\left.\mathrm{NO}_{3}{ }^{-}\right)$.

The occurrence of denitrification in SZ during the ADPs was evident by the quick decrease of $\mathrm{NO}_{3}$ in Section 3.2 (Figure 3). This could be best illustrated with the additional results in this study with low $\mathrm{DO}$ (less than $0.5 \mathrm{mg} / \mathrm{L}$ ), during the three-day interval, $\mathrm{NO}_{3}{ }^{-}$in $\mathrm{SZ}$ can be fully removed by improved denitrification $[7,8,10]$. The low $\mathrm{NO}_{3}{ }^{-}$concentrations in the early outflow process (Figure 5B) could reflect the $\mathrm{NO}_{3}{ }^{-}$level in the "old" water stored in SZ after ADPs, and during wetting periods, the gradual increase in the outflow of $\mathrm{NO}_{3}{ }^{-}$concentrations in the latter process could be a result of the mixing of the "old" water stored in $\mathrm{SZ}_{\text {with low }} \mathrm{NO}_{3}{ }^{-}$concentrations and the "new" inflow transported downward from the upper soil media layer with relatively high $\mathrm{NO}_{3}{ }^{-}$concentrations (Figure 5B). With the diminishing effect of "old" stored runoff, the outflow $\mathrm{NO}_{3}{ }^{-}$concentrations increased and even exceeded the inflow concentrations with $\mathrm{NO}_{3}{ }^{-}$leaching, and the net leaching of 
$\mathrm{NO}_{3}{ }^{-}$in the final outflow process likely originated from the nitrification with significant amounts of $\mathrm{NO}_{3}{ }^{-}$retained in the upper soil media layer during the ADPs.

The deeper SZ in this study was able to store more water to enable more denitrification during ADPs and provides more "old" water of low $\mathrm{NO}_{3}{ }^{-}$concentrations for water exchange with "new" inflow of high $\mathrm{NO}_{3}{ }^{-}$concentrations. Therefore, during wetting periods, systems with deeper $\mathrm{SZ}$ had more outflow of low $\mathrm{NO}_{3}{ }^{-}$concentrations and smaller amounts of outflow $\mathrm{NO}_{3}{ }^{-}$integrated over the whole outflow course, thus corresponding to higher $\mathrm{NO}_{3}{ }^{-}$removal performance (Figure $5 \mathrm{~B}$ ). The effectiveness of elevating $\mathrm{NO}_{3}{ }^{-}$removal by elevating $\mathrm{SZ}$ depths, is consistent with the results of Zinger et al [19] that showed a steady increase in $\mathrm{NO}_{3}{ }^{-}$removal efficiency ranging from $66 \%$ to $99 \%$ with the SZ depth from $450 \mathrm{~mm}$ to $600 \mathrm{~mm}$. However, their up to $99 \% \mathrm{NO}_{3}{ }^{-}$removal efficiencies in bioretention systems with SZ depths of 450 to $600 \mathrm{~mm}$ were consistently higher, probably owing to their low pollutant concentrations with TN concentration of $2.13 \mathrm{mg} / \mathrm{L}\left(\mathrm{NH}_{4}{ }^{+}\right.$conc. of $0.29 \mathrm{mg} / \mathrm{L}$, $\mathrm{NO}_{3}{ }^{-}$conc. of $0.74 \mathrm{mg} / \mathrm{L}, \mathrm{ON}$ conc. of $1.1 \mathrm{mg} / \mathrm{L}$, Melbourne, Australia) compared to that of $10 \mathrm{mg} / \mathrm{L}$ $\left(\mathrm{NH}_{4}{ }^{+}\right.$conc. of $2.5, \mathrm{NO}_{3}{ }^{-}$conc. of $2.5 \mathrm{mg} / \mathrm{L}, \mathrm{ON}$ conc. of $5.0 \mathrm{mg} / \mathrm{L}$, Shenzhen, China) in this study (Table 2). Also, the SZ in this study was the gravel sump layer and the increase of SZ depth implied increasing the gravel sump thickness and thus, increasing the quantity of stored runoff in this study, which could be used to indicate the functionality of SZ; whereas Zinger et al. [19] simply elevated the elbow pipes of the bioretention systems of fixed structure (the system consists of $400 \mathrm{~mm}$ sandy loam with vegetation, $400 \mathrm{~mm}$ fine sand, $30 \mathrm{~mm}$ transition river sand and $70 \mathrm{~mm}$ gravel layers) to different heights to create SZs of different depths and their SZs might encompass the soil and sand layers as well as the same $70 \mathrm{~mm}$ deep gravel sumps. Therefore, the advanced SZ design in our study can verify the effectiveness of SZ, and better optimize the design ratio of upper soil layer and bottom $\mathrm{SZ}$ for removing nitrogen.

However, though we have acknowledged the importance of a deep SZ, the increase of SZ gravel sump depth may incur additional excavation costs. Therefore, we suggest optimizing the nitrate removal by setting an appropriate depth-ratio of the upper media layer and $\mathrm{SZ}$ to promote the complete nitrogen cycle from $\mathrm{NH}_{4}{ }^{+}$to $\mathrm{NO}_{3}{ }^{-}$through nitrification and the permanent nitrogen removal of $\mathrm{NO}_{3}{ }^{-}$ by converting $\mathrm{NO}_{3}{ }^{-}$to gaseous nitrogen $\left(\mathrm{NO} / \mathrm{N}_{2} \mathrm{O} / \mathrm{N}_{2}\right)$ through denitrification (Figure 7), which also should be compromised with the cost.

\subsection{Organic Nitrogen Removal}

Likewise, ON removal could be attributed to many complex physical, chemical and microbial processes [7]. During wetting periods, ON could be removed substantially by retention and filtration in media layer and water exchange of stored runoff in SZ (Figure 7). Apart from that, during the 3-day ADPs, the upper soil media layer was mostly aerobic, mineralization (ammonification) can be promoted [34] to convert $\mathrm{ON}$ to $\mathrm{NH}_{4}{ }^{+}$. The bottom SZ added into bioretention systems formed an anaerobic condition under which mineralization might still occur, which was evident by the decrease of ON within 12-h drying periods (Figure 3). Therefore, ON removal could occur in both these layers and the introduction of $\mathrm{SZ}$ could be helpful to remove ON. The effectiveness of $\mathrm{SZ}$ on ON removal can be reflected by the significant difference of removal efficiencies between systems ( $p<0.05$ for ON).

The consistently low $\mathrm{ON}$ concentrations of each column during a wetting period indicated effective ON removal of bioretention systems (Figure 5C). Moreover, Figure 5C showed that the deeper the $\mathrm{SZ}$ was, the lower the $\mathrm{ON}$ concentration in the early outflow was. The reason might be that a deeper SZ provided more space for microbial mineralization to transform organic matter, leading to higher removal efficiency during the three-day drying periods (Figure 3). The results attested that ON removal could be slightly improved with the increase of SZ depths of bioretention systems.

\subsection{Total Nitrogen Removal}

TN removal in bioretention systems is a combined result of $\mathrm{NH}_{4}{ }^{+}, \mathrm{NO}_{3}{ }^{-}$, and $\mathrm{ON}$ removal which can be influenced by the hydrological and biotic processes in both the upper media layer and SZ under 
alternate drying and wetting conditions. As shown in Figure $7, \mathrm{NH}_{4}{ }^{+}$and $\mathrm{ON}$ could be effectively removed instantaneously due to retention and adsorption during wetting periods, while $\mathrm{NH}_{4}{ }^{+}, \mathrm{ON}$ and $\mathrm{NO}_{3}{ }^{-}$could mainly be removed via gradual nitrification, mineralization and denitrification processes during the ADPs (Figure 7). Therefore, TN removal in bioretention systems was determined by coupling the instantaneous hydrological water-exchange and chemical absorption during wetting periods with the gradual biotic removal, the former happened very quickly within one-hour wetting period, while the latter mainly occurred in the antecedent drying periods (Figure 3). The quasi-logistic curve-shaped variations of outflow $\mathrm{TN}$ concentrations similar to those of outflow $\mathrm{NO}_{3}{ }^{-}$concentrations showed that the fluctuations of TN removal were mainly controlled by $\mathrm{NO}_{3}{ }^{-}$(Figure 5B,D). Instead, higher $\mathrm{NH}_{4}{ }^{+}$and $\mathrm{ON}$ removal with deeper $\mathrm{SZ}$ mainly accounted for significantly increased TN removal $(p<0.05)$ owing to their high removal efficiencies (Figure 6).

The deeper SZ contained more "old" stored runoff, which could improve plants' growth with more moisture during the ADPs. Especially, it could form an anaerobic area for biotic removal pathways during the ADPs, and store a lager quantity of water for hydrological water-exchange removal pathways during wetting periods, which are important to $\mathrm{NO}_{3}{ }^{-}$and $\mathrm{ON}$ removal. As a result, SZ could help solve the fluctuations of nitrogen removal, the extent of which was dependent on the stored runoff quantity during the ADPs. However, in reality, the selection of suitable SZ depths of bioretention systems for nitrogen removal should be compromised with the construction costs according to local pollution and meteorological condition.

\section{Conclusions}

$\mathrm{NH}_{4}{ }^{+}$removal efficiency in bioretention systems was consistently high through effective adsorption in soil layer, not varying with the increasing SZ depth, whereas $\mathrm{ON}$ and $\mathrm{NO}_{3}{ }^{-}$ removal efficiency significantly increased with the SZ depth increasing from 0 to $600 \mathrm{~mm}$ due to increased mineralization and denitrification. $\mathrm{NO}_{3}{ }^{-}$concentrations over the outflow process presented quasi-logistic curve-shaped variations over time: being low in the early outflow process, sharply increasing thereafter, and in the final process flattening with the ultimate concentrations exceeding the inflow concentrations. $\mathrm{NO}_{3}{ }^{-}$leaching often occurred in the final outflow process without regard to the SZ depth. With the increase of SZ depth, quasi-logistic curve-shaped variations were observed with the longer duration of low $\mathrm{NO}_{3}{ }^{-}$concentrations in the early outflow process and less $\mathrm{NO}_{3}{ }^{-}$ leaching in the latter outflow process. The incorporation of a deeper SZ proved beneficial to nitrogen removal and maintenance of bioretention functionality. The effectiveness of increasing SZ depths to promote $\mathrm{TN}$ removal was attributed to larger amounts of stored runoff where denitrification of $\mathrm{NO}_{3}{ }^{-}$ and mineralization of ON occurred during the ADPs.

One possible direction for future nitrogen removal improvement is to transport the products of nitrification $-\mathrm{NO}_{3}{ }^{-}$- from the upper soil media to the $\mathrm{SZ}$ occasionally during ADPs to further increase the $\mathrm{NO}_{3}{ }^{-}$removal, which, however, requires additional care in the field. Also, more detailed studies and in-depth analyses are needed to quantify the effect of SZ in this "black box" - a bioretention system under alternate drying and wetting conditions.

Acknowledgments: This research was supported by The National Natural Science Foundation of China (41603073), Shenzhen Science and Technology Development Fund Project (JCYJ20150518092928547), National Water Pollution Control and Management Technology Major Projects (No. 2013ZX07501005), and the project of Shenzhen Municipal Development and Reform Commission (Discipline construction of watershed ecological engineering). The authors are deeply grateful to Ming Cheng, Kangmao He, Yanyan Zheng for helping with laboratory work and analysis. Finally, the authors would like to thank, in particular, the invaluable support received from Meiyue Ding over the years.

Author Contributions: Chuansheng Wang, Huapeng Qin and Fan Wang conceived and designed the experiments; Chuansheng Wang, Xueran Li and Xiangfei Zeng performed the experiments; Chuansheng Wang and Fan Wang analyzed the data; Fan Wang and Shaw-Lei Yu contributed experimental analysis tools; Chuansheng Wang and Fan Wang wrote the paper; Huapeng Qin and Shaw-Lei Yu helped review and edit the paper.

Conflicts of Interest: The authors declare no conflict of interest. 


\section{References}

1. United States Environmental Protection Agency (US EPA). Renewed Call to Action to Reduce Nutrient Pollution and Support for Incremental Actions to Protect Water Quality and Public Health; United States Environmental Protection Agency: Washington, DC, USA, 2016. Available online: https:/ /www.epa.gov/sites/production/ files/2016-09/documents / renewed-call-nutrient-memo-2016.pdf (accessed on 22 September 2016).

2. Driscoll, C.T.; Whitall, D.R.; Aber, J.D.; Boyer, E.W.; Castro, M.S.; Cronan, C.S.; Groffman, P.; Hopkinson, C.; Lambert, K.; Lambert, K.; et al. Nitrogen Pollution in the Northeastern United States: Sources, Effects, and Management Options. BioScience 2003, 53, 357-374. [CrossRef]

3. Taylor, G.D.; Fletcher, T.D.; Wong, T.H.F.; Breen, P.F.; Duncan, H.P. Nitrogen composition in urban runoff: Implications for stormwater management. Water Res. 2005, 39, 1982-1989. [CrossRef] [PubMed]

4. Liu, J.; Sample, D.J.; Bell, C.; Guan, Y. Review and Research Needs of Bioretention Used for the Treatment of Urban Stormwater. Water 2014, 6, 1069-1099. [CrossRef]

5. Jia, H.; Yao, H.; Shaw, L.Y. Advances in LID BMPs research and practice for urban runoff control in China. Front. Environ. Sci. Eng. 2013, 7, 709-720. [CrossRef]

6. Davis, A.P.; Shokouhian, M.; Sharma, H.; Minami, C.; Winogradoff, D.A. Water quality improvement through bioretention: Lead, copper, and zinc removal. Water Environ. Res. 2003, 75, 73-82. [CrossRef] [PubMed]

7. Davis, A.P.; Shokouhian, M.; Sharma, H.; Minami, C. Water quality improvement through bioretention media: Nitrogen and phosphorus removal. Water Environ. Res. 2006, 78, 284-293. [CrossRef] [PubMed]

8. Hatt, B.E.; Fletcher, T.; Deletic, A. Hydraulic and Pollutant Removal Performance of Fine Media Stormwater Filtration Systems. Environ. Sci. Technol. 2008, 42, 2535-2541. [CrossRef] [PubMed]

9. Hunt, W.F.; Davis, A.P.; Traver, R.G. Meeting Hydrologic and Water Quality Goals through Targeted Bioretention Design. J. Environ. Eng. 2012, 138, 698-707. [CrossRef]

10. Lynn, T.J.; Yeh, D.H.; Ergas, S.J. Performance and longevity of denitrifying wood-chip biofilters for stormwater treatment: A microcosm study. Environ. Eng. Sci. 2015, 32, 321-330. [CrossRef]

11. Palmer, E.T.; Poor, C.J.; Hinman, C.; Stark, J.D. Nitrate and phosphate removal through enhanced bioretention media: Mesocosm study. Water Environ. Res. 2013, 85, 823-832. [CrossRef] [PubMed]

12. Rycewicz-Borecki, M.; Mclean, J.E.; Dupont, R.R. Nitrogen and phosphorus mass balance, retention and uptake in six plant species grown in stormwater bioretention microcosms. Ecol. Eng. 2017, 99, 409-416. [CrossRef]

13. Hunt, W.; Jarrett, A.; Smith, J.; Sharkey, L. Evaluating Bioretention Hydrology and Nutrient Removal at Three Field Sites in North Carolina. J. Irrig. Drain. Eng. 2006, 132, 600-608. [CrossRef]

14. Bratieres, K.; Fletcher, T.D.; Deletic, A.; Zinger, Y.A. Nutrient and sediment removal by stormwater biofilters: A large-scale design optimisation study. Water Res. 2008, 42, 3930-3940. [CrossRef] [PubMed]

15. Davis, A.P.; Hunt, W.F.; Traver, R.G.; Clar, M. Bioretention technology: Overview of current practice and future needs. J. Environ. Eng. 2009, 135, 109-117. [CrossRef]

16. Collins, K.A.; Lawrence, T.J.; Stander, E.K.; Jontos, R.J.; Kaushale, S.S.; Newcomer, T.A.; Grimmg, N.B.; Ekberg, M.C. Opportunities and challenges for managing nitrogen in urban stormwater: A review and synthesis. Ecol. Eng. 2010, 36, 1507-1519. [CrossRef]

17. Sharkey, L.J.; Hunt, W.F. Hydrologic and water quality performance of four bioretention cells in central North Carolina. In Proceedings of the Watershed Management Conference-Managing Watersheds for Human and Natural Impacts: Engineering, Ecological, and Economic Challenges, Williamsburg, VA, USA, 19-22 July 2005; pp. 833-842.

18. Blecken, G.; Zinger, Y.; Deletic, A.; Fletcher, T.; Hedstrom, A.; Viklander, M. Laboratory study on stormwater biofiltration: Nutrient and sediment removal in cold temperatures. J. Hydrol. 2010, 394, 507-514. [CrossRef]

19. Zinger, T.; Fletcher, T.D.; Deletic, A.; Blecken, G.T.; Viklander, M. Optimisation of the nitrogen retention capacity of stormwater biofiltration systems. Presented at the 6th International Conference on Sustainable Techniques and Strategies in Urban Water Management, Lyon, France, 24-28 June 2007.

20. Zinger, Y.; Deletic, A.; Fletcher, T.D. The effect of various intermittent wet-dry cycles on nitrogen removal capacity in biofilters systems. Presented at the 13th International Rainwater Catchment Systems Conference and 5th International Water Sensitive Urban Design Conference, Sydney, Australia, 21-23 August 2007. 
21. Zinger, Y.; Blecken, G.; Fletcher, T.D.; Viklander, M.; Deletic, A. Optimising nitrogen removal in existing stormwater biofilters: Benefits and tradeoffs of a retrofitted saturated zone. Ecol. Eng. 2013, 51, 75-82. [CrossRef]

22. Soberg, L.C.; Viklander, M.; Blecken, G. Do salt and low temperature impair metal treatment in stormwater bioretention cells with or without a submerged zone. Sci. Total Environ. 2016, 579, 1588-1599. [CrossRef] [PubMed]

23. Amir, A.; Asher, B. Use of Cotton as a Carbon Source for Denitrification in Biofilters for Groundwater Remediation. Water 2017, 9, 714. [CrossRef]

24. Dietz, M.E.; Clausen, J.C. Saturation to Improve Pollutant Retention in a Rain Garden. Environ. Sci. Technol. 2006, 40, 1335-1340. [CrossRef] [PubMed]

25. Zhang, Z.; Rengel, Z.; Liaghati, T.; Antoniette, T.; Meney, K. Influence of plant species and submerged zone with carbon addition on nutrient removal in stormwater biofilter. Ecol. Eng. 2011, 37, 1833-1841. [CrossRef]

26. Zhang, Z.; Rengel, Z.; Meney, K. Interactive effects of nitrogen and phosphorus loadings on nutrient removal from simulated wastewater using Schoenoplectus validus in wetland microcosms. Chemosphere 2008, 72, 1823-1828. [CrossRef] [PubMed]

27. Passeport, E.; Hunt, W.F.; Line, D.E. Field study of the ability of two grassed bioretention cells to reduce storm-water runoff pollution. J. Irrig. Drain. Eng. 2009, 135, 505-510. [CrossRef]

28. Monash University. Adoption Guidelines for Stormwater Biofiltration Systems: Facility for Advancing Water Biofiltration; Monash University: Melbourne, Australia, 2009.

29. Melbourne Water. WSUD Engineering Procedures: Stromwater; CSIRO Publishing: Melbourne, Australia, 2005.

30. Department of Environmental Resources. Bioretention Manual. Environmental Services Division; Department of Environmental Resources: The Prince George's County, MD, USA, 2007.

31. Blecken, G.; Zinger, Y.; Deletic, A.; Fletcher, T.; Viklander, M. Impact of a submerged zone and a carbon source on heavy metal removal in stormwater biofilters. Ecol. Eng. 2009, 35, 769-778. [CrossRef]

32. Huang, J.; Du, P.; Ao, C.T.; Lei, M.H.; Zhao, D.Q.; Ho, M.; Wang, Z. Characterization of surface runoff from a subtropics urban catchment. J. Environ. Sci. 2007, 19, 148-152. [CrossRef]

33. American Public Health Association; American Water Works Association; Water Environment Federation. Standard Methods for the Examination of Water and Wastewater, 22nd ed.; American Public Health Association, American Water Works Association, Water Environment Federation: Washington, DC, USA, 2012.

34. Payne, E.G.; Fletcher, T.D.; Cook, P.L.; Deletic, A.; Hatt, B.E. Processes and drivers of nitrogen removal in stormwater biofiltration. Crit. Rev. Environ. Sci. Technol. 2014, 44, 796-846. [CrossRef]

35. Geronimo, F.K.F.; Maniquiz-Redillas, M.C.; Kim, L.H. Fate and removal of nutrients in bioretention systems. Desalin. Water Treat. 2015, 53, 3072-3079. [CrossRef]

36. Peterson, I.J.; Igielski, S.; Davis, A.P. Enhanced denitrification in bioretention using woodchips as an organic carbon source. J. Sustain. Water Built Environ. 2015, 1. [CrossRef]

37. Brown, R.A.; Hunt, W.F. Underdrain configuration to enhance bioretention exfiltration to reduce pollutant loads. J. Environ. Eng. 2011, 137, 1082-1091. [CrossRef]

38. Subramaniam, D.; Mather, P.B.; Russell, S.; Rajapakse, J. Dynamics of Nitrate-Nitrogen Removal in Experimental Stormwater Biofilters under Intermittent Wetting and Drying. J. Environ. Eng. 2016, 142. [CrossRef]

(C) 2018 by the authors. Licensee MDPI, Basel, Switzerland. This article is an open access article distributed under the terms and conditions of the Creative Commons Attribution (CC BY) license (http://creativecommons.org/licenses/by/4.0/). 